\title{
Annotated Translation of Al-Madkhal fī 'ilmil-Farā'id (A simplified guide to the Islamic law of inheritance)
}

\author{
Sulayman Adeniran Shittu Ph.D \\ Department of Arabic and Islamic Studies, Faculty of Arts, University of Ibadan,Nigeria
}

\begin{abstract}
Annotated Translation of Al-Madkhal fí ilmil-Farā'id (A simplified guide to the Islamic law ofinheritance), a book Written by Al-Sayyid 'Ali bn Abī Bakr Al-Muthannā bn Alhāj Abdullahi Nyāss AlKawlakhī Al-Tijānī; MayAllah be pleased with all of them (Amīn). Many nuclear and extended Muslim families are in disarray and live in fracas after the deceased of a member due to the sharing of his or her property meant for the heirs. Therefore, some issues arise from inheritance provoke emotions and escalate irrational behaviour among the heirs. Consequently, many peaceful homes were turned into chaos be it the wife or husband, father or mother, son or daughter. The book simplified the proportion allotted to each of the beneficiaries in the family. It will definitely guide young and old English audience on how the property of a departed soul could be shared in accordance with the sources of Islamic law. Leading questions were supplied at the end of the book which could be regarded as a self assessment for the reader.
\end{abstract}

Keywords: 'Ali bn Abī Bakr Al-Muthannā, A simplified guide, îlmil-Farā'id, proportion allotted, the heirs

\section{INTRODUCTION}

\section{About the Book}

Religion as a system of belief is indeed a very sensitive issue, not only among Nigerians but also in other parts of the world. The reasons being that, some issues arise from inheritance provoke emotions and escalate irrational behaviour among the heirs. Consequently, many peaceful homes were turned into chaos just for the departure of a member of the family. Be it the wife or husband, father or mother, son or daughter.

Islamic Law is a law that guides Muslims' lives from the cradle to the grave. This law guides live of a people in a particular domain which is precipitated by the existence of Islam in such place. The law of inheritance is a knowledge that every soul who believes that death is inevitable must agitate to understand. As the Prophet Muhammad (SAW) affirmed this in his Hadith "Learn about inheritance and impact it to other people because soonest, this problem may arise until there may be differences on inheritance between two people without settlement".

Many nuclear and extended families are in disarray and live in fracas after the deceased of a member due to the sharing of his or her property meant for the heirs. The book simplified the proportion allotted to each of the beneficiaries in the family. It will definitely guide young and old on how the property of a departed soul could be shared in accordance with the sources of Islamic law. Leading questions were supplied at the end of the book which could be regarded as a self assessment for the reader. Whoever reads a copy of the book will be able to educate his/her family. Allah says in the Qur'an 15:24

\section{Meaning:}

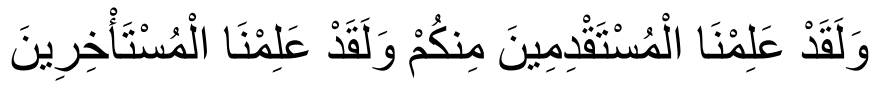

"And we have already known the preceding among you and we have already known the later".

\section{Brief Biography of the Author}

His full name is Al-Sayyid 'Ali bn Ab̄̄ Bakr Al-Muthannā bn Alhāj Abdullāhi Nyāss Al-Kawlakhī AlTijānī (May Allah be pleased with all of them). He is a son of Alhaji Abu Bakri al-Muthannā, one of the caliphates of the renowned spiritual master, Shaykhul - Islam Alhaji Ibrahim (Nyass) of Kawlakh, Senegal. He acquired his rudimentary education from his guardian - Sayyid 'Ali Ciise. He acquired his secondary education in Kawlakh and later proceeded to Cairo where he obtained Bachelor of Arts from Al-Azhar University. During his educational tour, he received Islamic education from many scholars especially from the erudite scholar, Shaykh Muhammad Nas'alī,Fazi who taught him this branch of knowledge (Islamic law of Inheritance) in Morroco. 


\title{
English Translation
}

\section{Al-Madkhal fì ilmil-Farā'id(A simplified guide to the Islamic law of inheritance) Written by}

\author{
Al-Sayyid 'Ali bn Ab̄̄ Bakr Al-Muthannā bn Alhāj Abdullahi Nyāss Al-Kawlakhi Al-Tijān̄i; May Allah \\ be pleased with all of them (Amīn)
}

\section{Words from the Author \\ In the name of Allah the Merciful the Beneficent}

Praise is to Allah, the Lord of the world; may the blessing and peace of Allah be on our noble master Muhammad, the first teacher, and may it be on his household, his companions and those who righteously follow him till the Day of Judgment.

The draft of this book certainly completed in the house of a brother, Alhaji Ahmad As-Shāfiiyy Agege, Lagos in Nigeria.

I also hope that whoever lays his hand on the book would recite Suratul-Fatiha for my Spiritual master Shaykhil - Islam Alhaji Ibrahim (Nyass) and his caliphates such as my father Alhaji Abu Bakri al-Muthannā, my guardian Sayyid 'Ali Ciise, so also AlhajiAbdullahi and particularly (the reward of the recitation) should also be extended to the one that taught me this branch of knowledge in person of Shaykh Muhammad Nas'alī, Fazi in Morroco, may Allah be pleased with him and lodge him in his spacious paradise alongside with the prophets, the truthful ones, the martyrs, and the virtuous, the good companions. And may Allah protect the generality of his Caliphates with sound health and long lives.

Written by:

TalibRidol-Lah Shaykh Ibrahim, 'Sayyid 'Ali bn Abu Bakri al-Muthannā bn Alhaji Abdullāhi (Nyass)

\section{Preface}

In the name of Allah, the Merciful, the Merciful. Praise is to Allah who honours the people who possess knowledge by moving them closer to Himself. And He says: They are not equal those who know not and those who know, also says: Only knowledge ones among his servants fear Allah. And may the blessing and peace of Allah be on our master, Muhammad who says "Whomsoever Allah wishes the best for, He shall make him understand His religion" or as reported. And may the blessing extend to his household and companions those who Allah revealed this in their respect "were it not for a group among them from various sects that blessed toward understanding of religion, that they may warn their people by the time they return to them so that they may be careful (of their enemies) And those who righteously follow them till the day of resurrection.

Afterwards, surely some of the knowledge aspirants made a request from me that I should write a book on the law of inheritance. And I sought advice on this from another erudite scholar who later told me that he has interceded with the prophet in that regard that (and the result as that), I should help him on (the request) And as a result of this, I sought for high aiming ambition of Shaykh in the beginning as thus:

O! The high aiming ambition of Shaykh Come over to us in this project and have mercy on me by showing me a way that will bring us the success" Also sought for the support of Allah, for His guidance to the righteous path.

\section{Law of Inheritance}

Is a knowledge that teaches the proportion of each heir from the left property whether male or female or hermaphrodite.

Evidence from the Qur'ān "For men there shall be a share from the properties left behind by the parents or the relatives whether few or plenty a certain proportion allotted (to them)

And in the Hadith, "Surely, Allah does not entrust the sharing of your heirs to a close angel neither does He entrust it to a sent prophet, but He Himself takes over the sharing in a very clear measure. And the prophet says again "There is no will for the heir(s)"

In consensus opinion of the Muslim scholars of various epochs unanimously agreed that surely the inheritance is compulsory and lawful, nobody shall avoid it except he that is against the Qur'ān and Sunna; the idle player of his religion

Factors of Inheritance

There are three reasons for inheritance: -

Relation: Such as father, son, grandfather, mother, the grandmother, daughter, grand daughter, etc. 
Slavery: Whoever set a slave free. The slave is entitled to his properties, provided he has no heir. Marriage: Husband can inherit from his wife and vice-versa.

\section{Conditions for Inheritance}

For inheritance there are three conditions attached to it:

1. Confirmation of the death of the deceased.

2. Existence of the heir after him.

3. Availability of properties to be shared.

A poet says:

The factors to inheritance by the people are three, each shall benefit the shares of bequeath.

They are: Marriage, slavery and relation, beyond these, there is no other link (to the inheritors).

\section{Impediments to Inheritance}

For the inheritance are impediments put together under this acronym:

\section{“ISH” " $\underline{L A K A}$ " “ $\underline{R I S Q}$ ”}

1. Still born baby shall not inherit; child born without breathing would not also inherit or be inherited.

2. Doubt over who died first: like a group of relatives that died that they could not determine who died first or last; there shall not be inter-inheritance among them.

3. Allegation of Adultery: If the husband and wife underwent the process of curse, and one of them died before the appointed period lapses or not too far after the period, they shall not inherit each other.

4. Infidelity: Whoever changes his religion shall not inherit or be inherited provided he died in his/her adopted religion.

5. Slavery: The slave shall not inherit from the properties of his consanguine that are not slaves for he is under the custody of a master and he has nothing to give out.

6. A bastard: A bastard shall not inherit from the properties of his acclaimed father except that he will inherit from his mother, for what is not in existence in law is like what is not in existence physically.

7. Deliberate Killing: One who deliberately kills shall not inherit anything. For he, was accused of the untimely death of the deceased. But provided that he is exonerated of the killing, he shall not inherit from the soul prize again. Al- Tilmisāniyyah Author has pointed to this as thus:

What (serves as) impediments to inheritance be sure, are six

Five out of them are total impediments

They are: change of religion, slavery and deliberate killing

And doubt cast on the first to have died try to understand my submission.

And one is just a situational impediment

It is the one that brings about confusion.

\section{Types of Inheritance}

The inheritance shall be on compulsory share or by entitlement

Compulsory share: is what the supreme jurist (Allah) affirms as a share of each heir in His Glorious book and the prophetic tradition.

How many types of Compulsory Share

The types of the share are six: $1 / 2,1{ }_{3},{ }_{3} /, 1 / 4,{ }_{6} /{ }_{6},{ }_{8}$

Those entitled to $1 / 2$ of the properties: daughter, granddaughter, full sister, paternal sister and husband.

Those entitled to ${ }^{1 /}{ }_{3}$ : Mother, maternal brother (with absence of children)

Those entitled to ${ }^{2 /}$ : The daughters, full sisters and paternal sisters.

Those entitled to $1 / 4$ : Husband and wife (in absence of child)

Those entitled to ${ }_{6}^{1 /}$ : Father, Mother, grandfather, grandmother, granddaughter, maternal sister, maternal brother, paternal sister.

Those entitled to ${ }^{1 /}{ }_{8}$ : Wife or Wives (with the presence of child or children).

\section{What is entitlement?}

It is the collection of the whole property/money of the inheritance or the remaining ones from those entitled to the Heir or some portions of the property left with somebody who is in the same category.

\section{Who are the Heirs?}

Those who entitled to the heirs are: the father, the grandfather, the daughter, the daughter of the son (even if the mother is low) the grandmother, the nephew sister by the same father and mother, the husband, the wife, the nephew brother and sister, the maternal sisters and daughters. 
Who can lawfully inherit?

They are Mother, grandmother, wife, husband, maternal brother and sister.

\section{Who inherits by entitlement alone?}

The son, the great grandson (even if low) the nephew, the father's brother, the son of the nephew, the son of father's brother, the paternal uncle, the uncle of father's brother, the sons of the paternal uncles, the freed slaves and his wards and the Muslim community treasury.

Those who combine rights and the entitlement: Father, Grandfather (if ascendant) Daughter, Daughter of son, Full sister and Paternal Sister.

\section{Prevention}

Prevention means denial of somebody's right and Legacy to inherit. It is of two kinds:

(a) Absolute Prevention; (b) Partial Prevention.

Absolute Prevention: Is the outright or complete prevention from the inheritance.

While the Partial prevention: means that the shares of the heirs may be gradually reduced from the highest to the lowest degree (i.e. from $1 /{ }_{3}$ to $1 / 6$ or from one - quarter $1 / 4$ to $1 / 8$ and so on.

\section{Category of those Entitlements that can inherit}

Those who are entitled to the heirs includes, the sons, fathers, brothers grand fathers, the sons of the brothers, the uncles and their sons, the freed slave and his wards and the Muslim community treasury.

The people that also remain for the heir

The son, the grand son (even if low) the father and the grand father (even though high) the nephew or brother to the father's brother the maternal uncle, the father's uncle, the son of maternal uncle, the son of father's uncle, the freed slave and his wards, the Muslim community treasury and the sisters if they are together.

"The sister becomes lawful to the property even if the deceased one has a daughter or daughters".

\section{Verses of Inheritance in the Holy Qur'ān}

There is a share for men and a share for women from what is left by parents and those who nearest related, whether the property be small or large is a legal share.

And when the relatives and the orphans and at Masākīn (the needy) are present at the time division, give them out of the property and speak to them words of kindness and justice.

And let those (executors and guardians) have the same fear in their minds as they would have for their own, if they had left weak offspring behind, so let them fear Allah and speak right words. Verily, those who unjustly eat up the property of orphans, they eat up only fire into their bellies, and they will be burnt in the blazing fire!

Allah commands you as regards your children's (inheritance) to the male, a portion equal to that of two females; if (there are) only daughters, two or more, their share is two of the property. If only one, her share is half. For parents a sixth share of the property to each if the deceased left children; if no children and the parents are the only heirs, the mother has a third; if the deceased left brothers or sisters the mother has a sixth. (The distribution in all cases is) after the payment of legacies he may have bequeathed or debts you know not which of them whether your parents or your children are nearest to you in benefit; (these feed shares) are ordained by Allah and Allah is Ever All-knower, All-wise.

In that which your wives leave, your share is a half if they have no children but if they have a child you get a fourth of that which they leave after payment of legacies that they may have bequeathed or debts in that which you leave (their your wives) share is a fourth if you leave no child but if you leave a child they get an eight of that which you leave after payment of legacies that you may have bequeathed or debts. If the man or woman whose inheritance is in question has left neither ascendants, but has left a brother or a sister, each one of the two gets a sixth but if more than two, they share in a third, after payment of legacies he or she may have bequeathed debts so, that no loss is caused to (anyone) This is a commandment from Allah; and Allah is Ever All-knowing, most forbearing (Q4: 7-12).

\section{Prophetic sayings on the importance of Law of Inheritance}

It is related by Muslim that Prophet (S.A.W) said that Allah Taālā has neither given the share of the inheritance to any pious angel nor to an anointed messengers, but (He had) laid the means of its sharing in a very clear way without extortion for the heirs.

The prophet encouraged having knowledge of inheritance when he says:

Learn about inheritance and impact it to other people because soonest, this problem may arise until there may be differences in inheritance between two people without settlement. 
The prophet (S.A.W) further says: knowledge is of Three kinds: Entire clear injunction verses from the Qur'ān, the prophetic sayings and the sound and very straight forward knowledge of inheritance.

The prophet also added: - Learn about the inheritance and teach others, and surely it is half of knowledge and first to be forgotten and perished among my community (Ummah).

\section{The condition of the father}

Examples:

1. The father can personally inherit the whole proportion on legality.

2. The father and the son: - The father would compulsorily inherit ${ }_{6}{ }_{6}$ of the property while the remaining goes to the son by entitlement.

3. The father and the Daughter: - The father can also inherit the $1 / 6$ of the property then $1 / 2$ belongs to the daughter and the remaining goes to the father by entitlement.

\section{Principle}

There are three conditions for the father:

1. Inheriting the whole property by entitlement in the absence of any other person surviving.

2. Inheriting $1 / 6$ of the property in the presence of male child by entitlement.

3. The father combines the legality and entitlement in the presence of female heir. No condition can prevent the father in the presence of any other heirs.

\section{Verses of Heir in the Holy Qur'ān}

7) For men is a share of what the parents and close relatives leave, and for women is a share of what the parents and close relatives leave, be it little or much - an obligatory share.

8) And when (other) relatives and orphans and the needy are present at the (time of) division, then provision for them (something) out of it (i.e. the estate) and speak to them words of appropriate kindness.

9) And let those (executors and guardians) fear (injustice) as if they (themselves) had left weak offspring behind and feared for them. So let them fear Allah and speak words of appropriate justice.

10) Indeed, those who devour the property of orphans unjustly are only consuming into their bellies fire. And they will be burned in a Blaze (i.e. Hellfire).

11) Allah instructs you concerning your children (i.e. their portions of inheritance): for the male, what is equal to the share of two female. But if there are (only) daughters, two or more, for them there are (only) daughters, two or more, for them is two thirds of one's estate. And if there is only one, for her is half. And for one's parents, to each one of them is a sixth of his estate if he left children. But if he had no children and the parents (alone) inherit from him, then for his mother is one third. And if he had brothers (and/or sisters), for his mother is a sixth, after any bequest he (may have) made or debt. Your parents or your children - you know not which of them are nearest to you in benefit (These shares are) an obligation (imposed) by Allah. Indeed, Allah is ever knowing and wise.

12) And for you is half of what your wives leave if they have no child. But if they have a child, for you is one fourth if what they leave, after any bequest they (may have) made or debt. And for them (i.e. the wives) is one fourth if you leave no child. But if you leave a child, then for them is an eight of what you leave, after any bequest you (may have) made or debt. And if a man or woman leaves neither ascendants nor descendants but has a brother or a sister, then for each one of them is a sixth. But if they are more than two, they share a third, after any bequest which was made or debt, as long as there is no detriment (caused). (This is) an ordinance from Allah and Allah is (most) knowing and for bearing. (Q.4:7-12)

\section{Condition of the grandfather \\ Examples}

1. The grandfather as a sole survivor will inherit the whole of the estate on the ground of entitlement.

2. The grandfather, the mother and the wife. The grandfather will take the remains after one third of the mother and one quarter of the wife with entitlement.

3. The grandfather, the son. The grandfather will then inherit ${ }^{1 /}{ }_{6}$ of the property as ordained (in the holy Qur'ān). The remains is for the son.

4. The grandfather and the daughter. The grandfather will inherit1/6 of the property as ordained, and the daughter will be given $1 / 2$ of the estate, while the grandfather will take the remains with entitlement.

\section{The principle}

The grandfather has three conditions

1. To inherit solely, if there is no offspring for the deceased

2. To inherit only the ${ }^{1 /}{ }_{6}$ of the property if there is a son or son's son 
3. To firstly inherit ${ }^{1 /}{ }_{6}$ as ordained (by the Qur'an) and then take whatever remains after the daughter has been given $1 / 2$ of the property, as there is female offspring for the deceased, the ordained share and entitlement will be combined by (the grandfather).

\section{The fourth condition for the grandfather}

\section{Examples:}

1. The grandfather and two full brothers. The grandfather will take ${ }_{3}^{1 /}$ of the property or equal share of the remaining will before the brothers.

2. The grandfather, the full brother and the full sister. The grandfather takes equal share of a male. The male brother will take a portion equal to that of two females (sisters).

3. The grandfather and two full sisters. Here the grandfather takes portion of the equal shared a male (that is) a portion equal to two females while the remaining will be shared among the sisters.

4. The grandfather and three paternal brothers. The grandfather will take ${ }_{3}^{1 /}$ of the property. The remains will be equally shared among the three brothers.

\section{The principle}

The fourth condition for the grandfather is to be with him two kinds of brother: The full brother or paternal brother. So far that there is no any member of right shares (Ashab al-faraid) among them, the grandfather will be given the property that suits him most among these two: either to take ${ }^{1 /}$ or a portion of equal shared, but if the brother is not up to two equal share is suitable for the grandfather

\section{The fifth condition for grandfather}

\section{Examples:}

1. The grandfather, full brother, wife and mother. Each of the grandfather and mother will take ${ }^{1 /} 6$ of the property $1 / 4$ will be given to the wife the remains will be equally shared among the brothers.

2. The grandfather, two paternal brothers, husband and mother. The grandfather will take the remaining ${ }^{1 /}{ }_{3}$ as a member of right shares, the husband will take $1 / 2$ and the mother ${ }^{1 /}{ }_{6}$ while the remaining property will be shared equally among the two brothers.

3. The grandfather, two full sisters husband and mother. The grandfather will take one portion of the equal shared property with the two sisters, $1 / 2$ of the property will be given to the husband, mother will take ${ }_{6}^{1 /}$ of the property due to the presence of the sisters.

\section{The principle:}

The fifth condition for the grandfather is to be with him two kinds of brothers, either full brother or paternal brother only, and a member of right share is among them. Then, the grandfather will inherit what suits him most among the following; ${ }^{1 /}{ }_{6}$ of the property, one third of the remaining property after the share of members of the right sharers, or a portion of the equal shared with the brothers. Should the equal share is more suitable favourble to him.

\section{The sixth condition for the grandfather, the grandfather and the residue} Examples

1. The grandfather, the full brother and the paternal brother. The grandfather will take ${ }_{3}^{1 /}$ of the property after that, the each of the brothers will take ${ }_{3}^{1 /}$, but the full brother will go back and collect half of the paternal brother's share.

2. The grandfather, the full brother and the paternal sister. To share the property equally is more suitable for the grandfather here.

Then, it will be shared into five, the grandfather will take two. The full brother two. Then the full brother will also collect half out the share of the paternal sister.

3. The grandfather, the full sister and the paternal sister. The property will be shared into four. The grandfather takes two while each of the sisters will take one. The full sister will turn to the paternal sister and take $1 / 2$ out of the share of paternal sister.

\section{The Principle}

The sixth condition for grandfather is to be with him, two kinds of brothers, paternal or full brothers. To share the property on equal bases is more suitable here for the grandfather; after the grandfather has taken his own share, the full brother will go back to the paternal brother and take out of his share in other to get what he supposed to have, if the grandfather does not exist.

The grandfather can only be excluded in presence of the father. 
Annotated Translation of Al-Madkhalfi'ilmil-Fara'id (A simplified guide to the Islamic law of...

\section{Condition of a Couple \\ Examples}

1. Husband and a full brother. The husband will take half of the property while the remaining $1 / 2$ goes to the full brother.

2. Husband and a daughter. The husband will take $1 / 4$ of the property and the daughter will be given half of it.

3. Husband and a son. The husband takes $1 / 4$ of the estate, while the son will take all the remaining property.

4. Wife and a full brother. The wife takes ${ }_{4}^{1 /}$ of the property and the rest will be given to the brother by right.

5. Two wives and a daughter. The two wives will take ${ }_{8}^{1 /}$ each. And half of the property will be given to the daughter.

6. Three wives and a son. The wives will take ${ }_{8}^{1 /}$ of the property while the remaining goes to the son by entitlement.

\section{The Principle}

There are two conditions for the husband

1. To inherit half of the property if the deceased have no son or grandson.

2. To inherit $1 / 4$ of the property if there is a son or son's son for the deceased

There are two conditions for the wife.

1. To inherit $1 / 4$ of the property if there is no son or grandson for the deceased

2. To inherit ${ }_{8}^{1 /}$ of the property if there is a son or grandson for the deceased

Both the husband and the wife cannot be excluded totally but their share can only be reduced.

\section{Condition of the Mother}

\section{Example:}

1. The mother and the full sister. The mother will take ${ }_{3}^{1 /}$ of the property and the half of it will be given to the sister. The remaining will be deposited into the Muslim community treasury.

2. The mother and the daughter. The mother will take ${ }^{1 /}{ }_{6}$ of the property for presence of the daughter; half of it will be given to the daughter, while the residue will be taken to the Muslim community treasury.

3. The mother and the son. The mother takes ${ }_{6}^{1 /}$ due to the presence of the son. The remaining will be taken by the son by entitlement.

4. The mother, full brother and a full sister. The mother takes ${ }^{1 /}{ }_{6}$ of the property due to presence of brothers. The remaining goes to the brothers.

\section{The Principle}

There are two conditions for the mother.

1. To inherit ${ }_{3}^{1 /}$ of the property if there is no son or grandson and if the brothers are not many.

2. To inherit ${ }^{1 /}{ }_{6}$ of the estate if there is son or grandson for the deceased and if the brother is not more than one.

They can never be totally excluded.

\section{Condition of Maternal Brother \\ Examples}

1. Maternal brother, husband and mother. The maternal brother will take ${ }_{6}^{1 /}$ of the property. The husband will take $1 / 2$ of it. While the mother will be given ${ }_{3}^{1 /}$.

2. Maternal brother, maternal sister and a wife. Maternal brother and sister will take share of ${ }_{3}{ }_{3}$ of the whole property equally. The wife will take $1 / 4$ of the property, while the remains will be taken to the Muslim community treasury.

3. Maternal sister, two aunts and grandmother, the sister will inherit one third of the property $\left({ }^{1 /}\right)$ and for the grandmother is $\left({ }_{6}^{1 /}\right)$ and the rest to the Muslim's Muslim community treasury.

4. The sister from the mother (Maternal sister).

\section{The Principle}

There are two conditions for the mother's brothers.

1. He inherit $\left({ }^{1 /}{ }_{6}\right)$ of the property if he is the only one

2. They inherit $\left({ }^{1 /}{ }_{3}\right)$ one third of the property if they are numerous.

He is expelled by the presence of one of the family's pillar; that is; the son, grandson even if he is lower. Father and grandfather even if he is higher. And daughter and granddaughter even if she is lower. 


\section{Condition of the Grandmother}

\section{Examples:}

1. The grandmother: The mother of the deceased will only inherit one sixth $\left({ }_{6}^{1 /}\right)$ of the money if she is the only survivor of the deceased and the rest will be for the Muslim's Muslim community treasury.

2. The grandmother, the deceased mother (mother of the husband or wife) and the grandmother who is the mother of the deceased father will share among themselves one sixth $\left({ }^{1 /}{ }_{6}\right)$ of the inheritance. The rest will be for the Muslim community treasury.

3. The grandmother; the mother of the deceased mother if the deceased is a female and the mother of the father will also share ${ }_{6}^{1 /}$ of the property among themselves.

4. The grandmother. Mother of deceased mother. The mother of his or her father will choose from his or her own side. The mother side will not share the equal ${ }^{1 /}{ }_{6}$ of the father side.

5. The great grandmother. The mother of the mother's father will not inherit because she has been deprived by the male.

6. The grandmother. Mother of the father's mother also will not inherit because she has been deprived by the male

7. The grandmother. The father's mother and the mother of the deceased; the grandmother will not inherit in the presence of the mother.

\section{The Principle:}

The only one condition for the grandmother and this is one sixth $\left({ }^{1 /} 6\right)$ whether she is one or they are two (mother of the father or mother of the mother).

The closer grandmother from the mother side will erase farer grandmother from the father's side and the opposite are not in consideration.

If they both rise to the nearness and farness, they will both share the ${ }^{1 /}$. And if any of the grandmothers' is separated by the male, she will not inherit.

And the mother erases the grandmother completely while the father erases the grandmother from his side and not from the mother's side.

\section{Position of the Daughter}

\section{Examples:}

1. The daughter the only inherits $1 / 2$ of the property, if she is the only survivor.

2. The daughter with another daughter inherits ${ }_{3}^{1 /}$ each from the property.

3. The daughter and the son: the inheritance will be to the male a portion equal to that of two females.

4. Three daughters will inherit ${ }_{3}^{2 /}$ of the whole property.

\section{The Principle}

Three conditions are for the daughter

1. She inherits half of the money if she is only survivor.

2. They all inherit ${ }_{3}^{2 /}$ if they are many.

A daughter and his brother will gain priority, for a male portion equal to that of two females. And a daughter will not be erased or given exemption forever (for the presence of male).

\section{Condition of the Son's Daughter}

Examples:

1. The son's daughter inherits half of the property if she is the only heir.

2. Two daughters of the son will both inherit ${ }_{3}{ }_{3}$ each from the property.

3. The Son's daughter and the grandson will inherit with superiority for a male is a portion equal to that of two females.

4. A grand daughter from the son together with direct daughter. The direct daughter will inherit half of the property while the grand-daughter will inherit one sixth $\left({ }_{6}^{1 /}\right)$ of the property. And whatever remains will go to the Muslim community treasury.

5. A grand-daughter from the son and two daughters. Both daughters will inherit one third each and the granddaughter of a son will inherit nothing.

6. The grand-daughter from the son and the son and nothing for the grand-daughter.

\section{The Principle:}

There are four conditions for the daughter of the son.

1. She inherits half of the money if she is the only survivor.

2. They all inherit one third $\left({ }_{3}^{1 /}\right)$ each if the are numerous 
3. The inheritance will be with superiority if she is with her brother.

4. She inherits one sixth $\left({ }_{6}^{1 /}\right)$ if she is with the direct daughter.

The presence of the son expels her and also when the daughter is numerous or more than one and when her place has been occupied by the real heir.

\section{The Condition of Full Sister}

1. The full sister will only inherit half of the property (if she is the only heir).

2. Two full sisters will inherit ${ }_{3}^{1 /}$ of the money each.

3. The full sister and full brother. The inheritance will be by priority for a male will be a portion equal to that of two females.

4. Full sister and the daughter. The daughter will take half of the property; the sister will take the rest with entitlement.

5. The full sister, the grandfather, the inheritance will be by superiority, the superior division will be for the grandfather (a male portion equal to that of two females).

\section{The Principle:}

There are five conditions for the full sister.

1. She inherits half of the property when she is only heir.

2. Each will inherit one third if they are more than one.

3. She inherits with superiority, for a male is a potion equal to that of two females.

4. She inherits by entitlement if she is with the direct daughters.

5. And the grandfather will take large portion. And full sister is expelled by the presence of the son, and grandson even if he is lower and the father, and all essential heirs.

\section{Condition of the Father's Sister (Aunt) \\ Examples}

1. The aunt takes half of the property when she is the only survivor.

2. Two aunts inherit ${ }_{3}^{1 /}$ each.

3. The aunt and the Uncle from the father. The inheritance will be by superiority: for a male's portion equals to that of two females.

4. The aunt and the full sister. The aunt will take ${ }_{6}^{1 /}$ of the property while the full sister takes half. And the rest will go to the Muslim community treasury.

5. The aunt and the real daughter. The aunt will take the rest property from what remain after the daughter has taken half.

6. The father's sister and the grandfather, the superior portion will be for the grandfather (a male portion equals to that of two females).

\section{The Principle}

There are six conditions for the father's sister (aunt).

1. She inherits half of the property if she is the only survivor.

2. They inherit ${ }_{3}^{2 /}$ of the property if they are many.

3. She inherits with her brother by priority of male over the female.

4. She inherits ${ }_{6}^{1 /}$ if she is with the full sister.

5. She inherits by entitlement the remaining property goes to her if she is in the midst of the daughters.

6. She inherits by entitlement together with the grandfather, and the grandfather's portion will be superior.

She will be prevented by the presence of the son and son of the son (grandson) even if he is lower. And daughters when many. These should be from full sisters and the legal heirs.

\section{Condition of the Son}

\section{Examples}

1. The son will inherit all wealth by entitlement if he is the only survivor.

2. The property shall be shared equally among the three sons.

3. The son and the daughter: the property will be shared by priority over the female heir (the male will have as much portion of two females).

\section{The Principle:}

There are three conditions for the son.

1. He shall Inherit the whole property as the only surviving heir

2. The property shall be shared between the brother and the sister. 
3. He shall have priority over his sister i.e. the male will have as much as the portion of 2 females. And the son shall not be deprived from the inheritance. Because he has no substitute that can represent him among the benefactors as mentioned in the Qur'ān.

\section{Conditions of the Grandson}

Examples

1. The grandson shall inherit the entire property if he is the only surviving heir.

2. Two grandsons: the property shall be equally shared between them.

3. Grandson and granddaughter: Male should have priority over the female i.e. a male will have as much portion of two females.

\section{The Principle}

There are three conditions governing the grand son's share

1. He shall inherit all the property as the only surviving heir.

2. The property shall be equally shared between him and his brother.

3. He shall be given priority over his sister and cousin i.e. the male will have as much portion of two females

And he shall be prevented in the presence of direct son, and as specifically mentioned in the Qur'an.

\section{Conditions of Full Brother}

\section{Examples}

1. The full brother shall inherit all the property by entitlement if he is the only surviving heir.

2. Two brothers: the properties shall be shared equally between them.

3. Full brother and full sister, the brother shall be given priority over the sister. i.e. the male will have as much portion as of two females

4. Property should be shared equally between the brother and the grandfather.

\section{The Principle}

There are four conditions for the brother

1. He shall claim all the estates if he is the only surviving heir or takes the remainder after the legal heirs have taken theirs.

2. The property shall be equally shared between him and his brothers.

3. He shall take priority over his sister, i.e. the male will have as much portion as that of two females.

4. He shall share with the grandfather, if the fraction favours the grandfather.

5. The presence of the son, grandson (irrespective of the generation of descent), father and the compulsory heirs mentioned in the Qur'ān shall debar him from the inheritance.

\section{Conditions of Half Brother (Paternal Brother)}

Examples

1. The half brother shall claim the property by entitlement if he is the only surviving heir.

2. Two half brothers: The property shall be shared equally between them.

3. Half brother and half (paternal) sister: the half brother shall edge over the half sister i.e. the male will have as much portion as of two females.

4. Half brother, mother, and husband: He shall inherit the remainder of the property after $1 / 3$ and $1 / 2$ of the mother and husband had been removed respectively of the whole property.

5. Half brother and grandfather: The property shall be shared equally between him and the grandfather.

\section{The Principle}

There are four conditions for the half brother.

1. He shall inherit all the property or remainder after the compulsory heirs (if available).

2. He shall share the property equally with his brother.

3. He shall take priority over his sister: i.e. the male will have as much as the portion of 2 females.

If the portion favours the grandfather most he shall share with grandfather.

The presence of son, grandson (irrespective of the generation of descent), the father, brother, and compulsory heirs as mentioned in the Qur'ān will debar him from the inheritance.

\section{Conditions of Son of the Brother (Nephew)}

1. The Nephew shall inherit all the properties if he is the only surviving heir.

2. The nephew, mother, maternal brother and husband. The husband will claim $1 / 2$ of the wealth, $1 / 3$ of the wealth goes to mother and $1 / 6$ goes to maternal brothers. 
3. The properties shall be equally shared among the nephews.

4. Nephew and Niece: the entire property belongs to the Nephew and nothing for the Niece. (daughters of a brother)

\section{The Principle}

There are two conditions for Nephew (Brother's son)

1. He shall claim all the property or remainder after the compulsory heirs.

2. Equal Sharing of the property with his brother of the same category. And the presence of the son, grandson (irrespective of the generation), the Father, Grandfather (irrespective of the generation), the brother, the paternal brother, and compulsory heirs would debar him (nephew) from the inheritance.

\section{Conditions of the nephew of paternal brother}

\section{Examples:}

1. The son of paternal brother shall inherit all the property by entitlement.

2. Two sons of paternal brothers (Nephews) shall equally share the property between both of them.

3. The Nephew (son) of the paternal brother and mother. He shall inherit all the remaining shares after $1 / 3$ of the mother.

\section{The Principle}

There are two conditions for paternal brothers' son (Nephew)

1. He shall inherit all the property or the remainder of the property after the compulsory heirs had taken theirs.

2. Division of property between him and his brother shall be equal.

And the presence of the son, grandson (irrespective of the generation), the Father, Grandfather (irrespective of the generation), the brother, the paternal brother, and compulsory heirs would debar him (nephew) from the inheritance.

\section{Conditions of the Full (Maternal) Uncle}

Examples:

1. Uncle shall inherit all the property if he is the only surviving heir.

2. Two Uncles shall share the property equally.

\section{The Principle}

There are 2 conditions for an Uncle 1.

2. Equal division of the property with his brother of the.

And the presence of the son, grandson (irrespective of the generation), the Father, Grandfather (irrespective of the generation), the brother, the paternal brother, and compulsory heirs would debar him (uncle) from the inheritance.

\section{Conditions of Paternal Uncle \\ Examples}

1. Paternal uncle shall inherit all the properties if he is the only surviving heir

2. Two paternal Uncles shall share the property equally between them.

\section{The Principle}

The are two conditions for paternal uncle i.

He shall inherit all the property if he is the only surviving heir.

Equal sharing of the property with his brother.

The presence of the son, grandson (irrespective of the generation), the Father, Grandfather (irrespective of the generation), the brother, the paternal brother, and compulsory heirs would debar him from the inheritance.

\section{Conditions of cousin (son of the uncle)}

Examples:

1.

The cousin shall inherit all the property in the absence of legal heirs

2.

$$
\text { Two cousins shall share the wealth equally }
$$

\section{The Principle}

There are two conditions for Cousin

1. He shall inherit all the property if he is the only surviving heir. 
2. Equal division of the property between the two brothers. He would be deprived of sharing the money by the existence of son, grandson how low it is and the father and the grandfather, how high it is.

The full brother and the half brother (from paternal side), the full uncle, the paternal uncle and the lawful sharers could also prevent him from the inheritance.

\section{Conditions of male cousin on the father's side}

Examples:

1. Male cousin to the father would alone inherit all the money/property by entitlement.

2. Male cousin to the father, male cousin to the father. The money would be divided equally between the two of them.

\section{The Principle:}

Male cousin to the father has two conditions:

1. His inheritance of all the money or that which remains after the shares of the rightful inheritors.

2. Dividing the money /property with his equal brother. He would be deprived from the share for the existence of son, grandson even if he is low. And the father and the grandfather even if he is highly placed. The full brother (from the paternal side). The uncle, and the paternal uncle and the male cousin of the full uncle the lawful sharers.

\section{Conditions of the Freed Slave}

Examples:

1. The freed slave would alone inherit all the money by entitlement.

2. The freed, slave and the mother, the freed shall inherit what remains of the mother's one third by entitlement.

3. The half freed slave shall inherit half of the property even if he is the only surviving heir. The quarter freed slave shall also inherit $1 / 4$ of the property, the ${ }_{3}^{1 /}$ freed slave (partial) shall also receive partial share of the deceased property.

\section{The Principles:}

The freed slave has two conditions

1. His inheritance of all the property if he is the only one. The existence of son, grandson, the full brother and the half brother (from the paternal side).

2. The full uncle, and the paternal uncle and the male cousin of the full uncle and the lawful sharers could also prevent him from the sharing.

\section{Relative of the Freed Slave Examples:}

1. The relatives of the freed such as the son, the grandson, the father, brothers, uncles and their children could stand in the position of the freed.

2. Likewise the partakers in the freed slave would inherit according to their rank in the paternal relationship, and if they are partakers in the freed slave their relatives would take their shares in consonance with the degree of freedom granted full or partial.

The existence of a son, grandson, how low it is, father and the grandfather, even if he is high. The full brother and the half brother and son of the half brother (from the paternal side); the full uncle, and the paternal uncle and the male cousin of the full uncle and the lawful sharers prevent the relative of the freed slave to inherit out of the deceased property.

\section{The Muslim Community Treasury Examples:}

If Muslim community treasury is not available in a community the money/property will be forwarded firstly to the schools, to the hospitals, to provide borehole for the community, to the mosques and using it to free Muslim prisoners.

Existence of son, grandson even if he is low, father or grandfather no matter how far he is, the full brother and the half brother and the son of the half brother (from the paternal side). The full uncle and the paternal uncle and the male cousin of the full uncle and the lawful sharers prevent the property to be forwarded as an endowment. We beseech Allah, the exalted to benefit all the Muslims with this effort and to bless it as He blessed His noble book (the Qur'ān) Amen (gain wider access and usefulness). 
Praise is unto Allah for the completion of Book I on Jurisprudential division. We hope to analyse some hypothetical property or wealth of a deceased in order to make fractional division easier for each family that read this book.

May Allah send peace and blessings on our master Muhammad, his household, and his companions.

The draft of the manuscript was neatly copied by Abdul Mumin Abdul Qadir.

The General Questions on Inheritance

1. What is law of inheritance?

2. Give it's reference from the Qur'ān

3. Give it's reference from the Hadith

4. Explain the causes of inheritance

5. Explain the condition of inheritance

6. Explain the impediments to inheritance

7. What is Entitlement?

8. What is compulsory sharer?

9. What is the rank of the entitlement?

10. Explain the states of the father

11. Explain fully the state of the grandfather.

12. Explain the conditions of husband and wife

13. Explain the conditions of the mother

14. Explain the conditions of the maternal brothers

15. Explain the condition of the grandmother

16. Explain the condition of the full sister

17. Explain the condition of the (paternal) half sister

18. Explain the conditions of the daughter

19. Explain the conditions of the grand daughter

20. Explain the conditions of the son

21. Explain the conditions of the grandson

22. Explain the condition of the brother

23. Explain the conditions of the paternal brother

24. Explain the conditions of the son (nephew) of paternal brother

25. Explain the conditions of the son (nephew) of paternal brother

26. Explain the conditions of the uncle

27. Explain the conditions of the paternal uncle

28. Explain the conditions of the cousin (son of uncle)

29. Explain the conditions of the cousin (son of paternal uncle)

30. Explain the conditions of the freed slave

31. Explain the condition of freed slave relatives

32. Explain who is preferable to be the next beneficiary when there is no survivor to inherit the property of a deceased and there is no Muslim community treasury. The mosque, school, hospital, the poor, debtors, prisoners among the Muslims.

33. Who are those (male) that are entitle to inheritance without their females?

34. When the men and women inherit equally?

35. Who are the compulsory sharers?

36. Who gave proportion of share? Allah, the messengers, or the angels, what is the reference to that in the Hadith?

May Allah guide us and be pleased with us ... The author.

\section{TABLE OF CONTENT}

1. Introduction

2. Law of Inheritance

3. Causes of Inheritance

4. Conditions of Inheritance

5. Impediment to inheritance

6. Type of Inheritance

7. Who are the Sharers of the bequeath?

8. Exclusion

9. Rank of the Entitlement

10. People that are entitle

11. The relevant verses to the law of inheritance in the Qur'ān 
12. The relevant prophet sayings on in the law of inheritance

13. The conditions of the Father

14. The conditions of the grandfather

15. The fourth condition for grandfather

16. The fifth condition for grandfather

17. The sixth condition for grandfather

18. The conditions of couple

19. The condition of mother

20. The condition of the maternal aunty

21. The Conditions of the grand mother

22. The conditions of the daughter

23. The conditions of grand daughter

24. Conditions of the full Sisters

25. Conditions of the paternal (half) sisters

26. Conditions of the son

27. Conditions of the grand son

28. Conditions of the full brother

29. Conditions of the paternal brother

30. Conditions of the nephew (son of brother)

31. Conditions of nephew (Son of paternal brother)

32. Conditions of the Uncle

33. Conditions of paternal uncle

34. The conditions of uncle son (cousin)

35. The conditions of paternal uncle son (cousin)

36. The condition of freed slave

37. Relatives of the freed slave

38. Public Muslim community treasury

39. General questions on the law of inheritance

40. Table content 